\title{
Hypothalamo-pituitary-thyroid function in anorexia nervosa: influence of weight gain
}

\author{
R D G LESLIE, A J ISAACS, J GOMEZ, P R RAGGATT, RICHARD BAYLISS
}

British Medical fournal, 1978, 2, 526-528

\section{Summary and conclusions}

The functional state of the hypothalamo-pituitarythyroid axis was assessed in 14 women and girls with anorexia nervosa when at low body weight and again in 12 cases after they had gained weight. Mean serum thyroxine concentrations were low before and after weight gain. Mean serum triiodothyronine (T3) concentrations were substantially reduced at low weight and doubled after weight gain, the absolute values being linearly correlated with body weight expressed as a percentage of the ideal. Concentrations of reverse T3 were greatly increased in some patients initially and fell with weight gain. Basal concentrations of thyroidstimulating hormone (TSH) were unchanged after weight gain but the TSH response to thyrotrophinreleasing hormone was significantly augmented; delayed patterns of response were found in seven out of 12 patients tested before and three out of 12 patients tested after weight gain.

Changes in the hypothalamo-pituitary-thyroid axis are common in anorexia nervosa and probably represent both peripheral and central adaptations to the altered nutritional state.

\section{Introduction}

Anorexia nervosa is characterised by severe weight loss and amenorrhoea associated with refusal to eat. ${ }^{1}$ There may be various abnormalities of endocrine function, and controversy persists about whether these are of pituitary or hypothalamic origin. ${ }^{2}$ Thyroid function is usually regarded as normal ${ }^{3}$ despite features suggestive of hypothyroidism, such as low basal metabolic rate, ${ }^{4}$ sinus bradycardia, and prolonged ankle reflex relaxation time. ${ }^{5}$ Recently serum triiodothyronine concentrations were reported to be low in anorexia. ${ }^{6}$ Thus hypothyroidism may be more common than has been thought.

We have studied a group of patients with anorexia nervosa to define their thyroid state and examine the relation between body weight and thyroid function during refeeding.

\section{Patients and methods}

Fourteen women and girls with typical anorexia nervosa? but no clinical evidence of thyroid disease were studied (table I). All were treated with an increased energy intake, reinforced by rewards for reaching target weights, together with continuing psychotherapy. No psychotropic drugs were given. The patients were first investigated

Department of Medicine, Westminster Hospital, London SW1P 2AP R D G LESLIE, MB, MRCP, registrar A J ISAACS, BM, MRCP, senior registrar J GOMEZ, DPM, MRCPSYCH, senior registrar shortly after admission to hospital while still at low body weight. Twelve were reinvestigated, some during and all after a period of weight gain, either while still in hospital or, in two cases, eight months after treatment was started while they maintained a stable weight as outpatients. No patient resumed menstruation during the study.

The patients were fasted overnight and an indwelling cannula was inserted into a forearm vein between 9 and $10 \mathrm{am}$ and kept patent with heparinised saline. An initial blood sample was taken for estimation of thyroid and pituitary hormones. A mixture of $200 \mu \mathrm{g}$ thyrotrophin-releasing hormone (TRH) and $100 \mu \mathrm{g}$ luteinising hormone/follicle-stimulating hormone-releasing hormone was given by rapid intravenous injection and further blood samples were taken 20 and 60 minutes later.

TABLE I-Age, weight on presentation, and percentage of ideal body weight at times of first and final tests

\begin{tabular}{|c|c|c|c|c|}
\hline \multirow{2}{*}{ Case No } & \multirow{2}{*}{ Age (years) } & \multirow{2}{*}{$\begin{array}{l}\text { Weight on } \\
\text { presentation } \\
(\mathrm{kg})\end{array}$} & \multicolumn{2}{|c|}{ "o, Ideal body weight } \\
\hline & & & Initial & Final \\
\hline $\begin{array}{r}1 \\
2 \\
3 \\
4 \\
5 \\
6 \\
7 \\
8 \\
9 \\
10 \\
11 \\
12 \\
13 \\
14\end{array}$ & $\begin{array}{l}14 \\
12 \\
23 \\
14 \\
17 \\
19 \\
16 \\
16 \\
18 \\
16 \\
41 \\
22 \\
25 \\
19\end{array}$ & $\begin{array}{l}40 \cdot 2 \\
31 \cdot 6 \\
36.5 \\
33 \cdot 8 \\
21 \cdot 5 \\
29 \cdot 5 \\
35.9 \\
39 \cdot 3 \\
35 \cdot 5 \\
31 \cdot 1 \\
24 \cdot 4 \\
31.9 \\
32 \cdot 6 \\
34.4\end{array}$ & $\begin{array}{l}81 \cdot 2 \\
70 \cdot 1 \\
79.5 \\
71 \cdot 3 \\
51 \cdot 2 \\
65 \cdot 8 \\
81.9 \\
79 \cdot 8 \\
71 \cdot 3 \\
62 \cdot 2 \\
57.4 \\
59 \cdot 9 \\
63.9 \\
66.2\end{array}$ & $\begin{array}{l}88.0 \\
96.3 \\
95.4 \\
95.7 \\
88.8 \\
98.5 \\
89.6 \\
85.5 \\
86.6 \\
86.9 \\
96.7 \\
86.7\end{array}$ \\
\hline
\end{tabular}

3,5,3'-Triiodothyronine (T3) and thyroxine (T4) were measured by radioimmunoassay using 8 -anilino-naphthyl-1-sulphonic acid to displace the hormones from serum binding protein and charcoalmethylcellulose to separate bound and free fractions. Thyrotrophin (TSH) was measured by a double antibody radioimmunoassay with guinea-pig antihuman TSH, the WHO first IRP $68 / 38$ being used as standard. All TSH specimens were measured in the same assay. Reverse T3 (3,3',5'-triiodothyronine; rT3) was kindly estimated in some samples by Dr W Ratcliffe, Glasgow Royal Infirmary, by radioimmunoassay. ${ }^{8}$ Prolactin and gonadotrophin measurements will be reported elsewhere.

The data were analysed with reference to body weight as a percentage of the ideal for each patient's age, height, and frame derived from the tables of the Metropolitan Life Insurance Company.

\section{Results}

THYROXINE

Before refeeding the mean total T4 concentration was $87.7 \pm$ SE $8.5 \mathrm{nmol} / 1$ (range 51-134) $(6.8 \pm 0.7 \mu \mathrm{g} / 100 \mathrm{ml}$; range $4.0-10.4)$, while after weight gain it was $87.0 \pm 5 \cdot 7 \mathrm{nmol} / \mathrm{l}$ (range 53-131) $(6.7 \pm 0.4 \mu \mathrm{g} / 100 \mathrm{ml}$; range $4 \cdot 1-10 \cdot 2)$ (table II). There was no significant difference between these means, though both were significantly lower $(P=0.005$ and $P=0.003$ respectively) than the mean in a group of 23 healthy male and female medical students $(109 \cdot 9+4 \cdot 2 \mathrm{nmol} / 1$, range $70-153 ; 8.5 \pm 0.3 \mu \mathrm{g} / 100 \mathrm{ml}$, range $5 \cdot 4-11.9)$. The normal reference range for our laboratory is $70-160 \mathrm{nmol} / 1(5 \cdot 4-12.4 \mu \mathrm{g} /$ $100 \mathrm{ml}$ ). Four of the 14 values were frankly subnormal before weight 
TABLE II - Serum concentrations of thyroxine (T4), triiodothyronine (T3), and reverse triiodothyronine ( $r T 3)$ before and after weight gain (results in some patients tested at intermediate weights not shown). Concentrations in nmol/l

\begin{tabular}{|c|c|c|c|c|c|c|}
\hline \multirow{2}{*}{$\begin{array}{l}\text { Case } \\
\text { No }\end{array}$} & \multicolumn{3}{|c|}{ Before weight gain } & \multicolumn{3}{|c|}{ After weight gain } \\
\hline & T4 & T3 & rT3 & T4 & T3 & rT3 \\
\hline \multirow{9}{*}{$\begin{array}{r}1 \\
2 \\
3 \\
4 \\
5 \\
6 \\
7 \\
8 \\
9 \\
10 \\
11 \\
12 \\
13 \\
14\end{array}$} & $\begin{array}{r}119 \\
87\end{array}$ & $\begin{array}{l}1.2 \\
0.8\end{array}$ & & 80 & $2 \cdot 1$ & $0 \cdot 14$ \\
\hline & 62 & $\begin{array}{l}1.6 \\
0.8\end{array}$ & $0 \cdot 18$ & $\begin{array}{l}53 \\
78\end{array}$ & $2 \cdot 1$ & 0.03 \\
\hline & 78 & 0.3 & 0.61 & 100 & $2 \cdot 3$ & $\begin{array}{l}0.07 \\
0.07\end{array}$ \\
\hline & $\begin{array}{l}93 \\
76\end{array}$ & 2.0 & $\begin{array}{l}0.84 \\
0.05\end{array}$ & $\begin{array}{r}100 \\
88\end{array}$ & $\begin{array}{l}1 \cdot 8 \\
2 \cdot 25\end{array}$ & $0 \cdot 16$ \\
\hline & 51 & & & 63 & & \\
\hline & $\begin{array}{r}102 \\
60\end{array}$ & $\begin{array}{l}1 \cdot 1 \\
0.96\end{array}$ & $0 \cdot 18$ & $\begin{array}{l}94 \\
89\end{array}$ & $1 \cdot 2$ & 0.08 \\
\hline & $\begin{array}{r}65 \\
112\end{array}$ & $\begin{array}{l}0.9 \\
0.73\end{array}$ & $\begin{array}{l}0.24 \\
1.39\end{array}$ & 78 & $2 \cdot 6$ & \\
\hline & 134 & & & 90 & $2 \cdot 4$ & 0.06 \\
\hline & 114 & 1.7 & & 131 & $2 \cdot 1$ & \\
\hline$\underset{\text { SE }}{\text { Mean }}$ & $87 \cdot 7 \pm 8 \cdot 5$ & $1 \cdot 10: 0 \cdot 15$ & $0.54 \div 0.19$ & $87 \cdot 0 \pm 5 \cdot 7$ & $2 \cdot 00 \pm 0 \cdot 14$ & $0 \cdot 10 \pm 0.02$ \\
\hline
\end{tabular}

Conversion: SI to traditional units-Serum T4: $1 \mathrm{nmol} / 1 \approx 0.08 \mu \mathrm{g} / 100 \mathrm{ml}$. Serum T3 and $\mathrm{rT} 3: 1 \mathrm{nmol} / 1 \approx 0.65 \mathrm{ng} / \mathrm{ml}$.

gain, as were two out of 12 after weight gain. There was no correlation between T4 and body weight.

\section{TRIIODOTHYRONINE}

Before refeeding the mean total T3 concentration was $1 \cdot 10 \pm$ $0 \cdot 15 \mathrm{nmol} / 1$ (range $0 \cdot 3-2 \cdot 0)(0 \cdot 7 \pm 0.09 \mathrm{ng} / \mathrm{ml} ;$ range $0 \cdot 2-1 \cdot 3$ ), rising to $2 \cdot 0 \pm 0 \cdot 14 \mathrm{nmol} / 1$ (range $1 \cdot 1-2 \cdot 6)(1 \cdot 3 \pm 0.09 \mathrm{ng} / \mathrm{ml}$; range $0 \cdot 7-1 \cdot 7$ ) after weight gain, this difference being highly significant $(P<0.001)$. Six out of 11 patients tested initially had values below the lower limit of our normal range $(1 \cdot 08-2.61 \mathrm{nmol} / 1 ; 0 \cdot 7-1 \cdot 7 \mathrm{ng} / \mathrm{ml})$, while all 11 tested after weight gain were within the normal range. All nine patients for whom paired results were available showed a rise in T3 $(\mathrm{P}<0.001)$. There was a highly significant correlation between serum T3 concentration and body weight expressed as a percentage of the ideal $(r=0.79 ; P<0.001-$ fig 1$)$.

\section{THYROXINE/TRIIODOTHYRONINE RATIO}

The mean T4/T3 ratio fell from $98.8 \pm 18.9$ to $48 \cdot 1 \pm 5 \cdot 7$ after weight gain $(P=0.018)$. There was a highly significant inverse correlation between the $\mathrm{T} 4 / \mathrm{T} 3$ ratio and the percentage of ideal

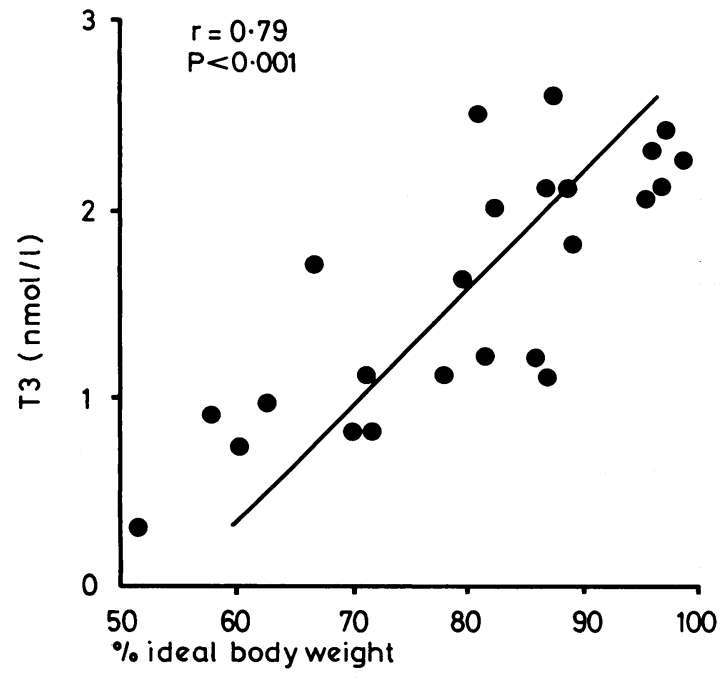

FIG 1-Correlation between serum triiodothyronine (T3) concentrations and percentage ideal body weight.

Conversion: SI to traditional units-Serum T3: $1 \mathrm{nmol} / 1 \approx$ $0.65 \mathrm{ng} / \mathrm{ml}$. body weight $(r=-0.71 ; P<0.001)$, though this was slightly weaker than that for $\mathrm{T} 3$ alone.

\section{REVERSE TRIIODOTHYRONINE}

There was a wide scatter of results for rT3 concentrations before weight gain (fig 2, table II), with three out of seven well above the normal range of $0.15-0.42 \mathrm{nmol} / 1(0.09-0.27 \mathrm{ng} / \mathrm{ml}$ ) (mean $0.27 \pm$ $0.01 \mathrm{nmol} / 1 ; 0.18 \pm 0.007 \mathrm{ng} / \mathrm{ml})$. The one subnormal value of $0.05 \mathrm{nmol} / 1(0.03 \mathrm{ng} / \mathrm{ml})$ was obtained on the sixth hospital day, when the patient's $T 3$ was $2.0 \mathrm{nmol} / 1(1.3 \mathrm{ng} / \mathrm{ml})$. After weight gain five out of seven patients tested had subnormal rT3 values, with two others at the lower limit of normal. Four patients tested both before and after weight gain showed a fall in rT3. There were significant inverse correlations between $\mathrm{rT} 3$ and percentage of ideal body weight $r=-0.61 ; P=0.025)$ and between $r T 3$ and $T 3(r=-0.55 ; P=0.028)$.

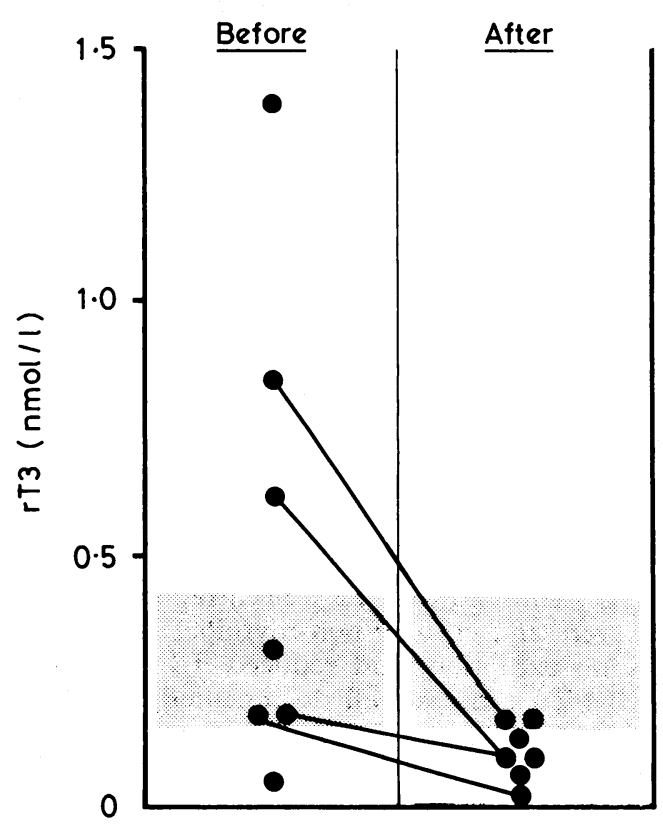

FIG 2-Serum reverse triiodothyronine (rT3) concentrations before and after weight gain. Normal range shaded.

Conversion: SI to traditional units-Serum rT3: $1 \mathrm{nmol} / 1 \approx 0 \cdot 65 \mathrm{ng} / \mathrm{ml}$.

\section{THYROTROPHIN}

One patient (case 11 ) had mildly raised basal TSH concentrations $(4.5-8.0 \mathrm{mU} / \mathrm{l})$ throughout the study (normal $<4.0 \mathrm{mU} / \mathrm{l}$ ) (table III). Eight of the other 12 patients tested had initial TSH concentrations at or below the detection limit of the assay $(1 \mathrm{mU} / 1)$, while after weight gain this was true of five out of 11 patients tested. There was no correlation between basal TSH values and weight.

Table IV shows the mean TSH concentrations before and after TRH injection in the 11 patients tested both before and after weight gain. With undetectable TSH concentrations being taken as $0.5 \mathrm{mU} / 1$ there was no significant difference between basal values, whereas TSH increments were significantly increased after weight gain at both 20 minutes $(P=0.016)$ and 60 minutes $(P=0.035)$, as was the maximal TSH increment $(P=0 \cdot 012)$. Comparison of the 20-minute and 60 -minute TSH values by the Wilcoxon ranked pairs test also showed a significant increase after weight gain $(P<0.01$ for both values). There was no correlation between post-TRH values of TSH or TSH increments and body weight.

Patterns of response were variable. The patient (case 11) with a raised basal TSH concentration showed delayed responses on the three occasions on which she was tested (the 60-minute TSH value being equal to or greater than the 20 -minute value). Before weight gain five of the other patients showed normal patterns of response, and six delayed patterns, four of which were also impaired (TSH increment $<5 \mathrm{mU} / \mathrm{l})$. After weight gain a normal response was characteristic, 
TABLE III-Serum concentrations of thyrotrophin (TSH), maximal TSH increment after TSH-releasing hormone (TRH) (Max $\triangle T S H)$, and pattern of response to $T R H(N=$ normal, $D=$ delayed) before and after weight gain (results in some patients tested at intermediate weights not shown)

\begin{tabular}{|c|c|c|c|c|c|c|}
\hline \multirow{2}{*}{$\begin{array}{l}\text { Case } \\
\text { No }\end{array}$} & \multicolumn{3}{|c|}{ Before weight gain } & \multicolumn{3}{|c|}{ After weight gain } \\
\hline & TSH (mU/l) & $\operatorname{Max} \triangle \mathrm{TSH}$ & Response & TSH (mU/l) & $\operatorname{Max} \triangle \mathrm{TSH}$ & Response \\
\hline $\begin{array}{r}1 \\
2 \\
3 \\
4 \\
5 \\
6 \\
7 \\
8 \\
9 \\
10 \\
11 \\
12 \\
13 \\
14\end{array}$ & $\begin{array}{r}2.0 \\
1.0 \\
<1.0 \\
<1.0 \\
<1.0 \\
1.1 \\
<1.0 \\
<1.0 \\
2.6 \\
61.0 \\
<1.0 \\
2.2 \\
<1.0\end{array}$ & $\begin{array}{r}11.0 \\
24.0 \\
6.7 \\
4.9 \\
2.2 \\
0.9 \\
3.5 \\
7.5 \\
\\
13.4 \\
18.0 \\
2.3 \\
8.7 \\
10.5\end{array}$ & $\begin{array}{l}\mathbf{N} \\
\mathbf{D} \\
\mathbf{N} \\
\mathbf{N} \\
\mathbf{D} \\
\mathbf{D} \\
\mathbf{D} \\
\mathbf{N} \\
\mathrm{D} \\
\mathbf{D} \\
\mathbf{D} \\
\mathbf{N} \\
\mathbf{N}\end{array}$ & $\begin{array}{r}<1.0 \\
<1.0 \\
2.0 \\
<1.0 \\
1.0 \\
<1.0 \\
4.0 \\
1.7 \\
3.0 \\
8.0 \\
3.8 \\
3.0\end{array}$ & $\begin{array}{r}10.5 \\
11.5 \\
5.0 \\
25.5 \\
5.4 \\
5.9 \\
8.0 \\
22.3 \\
21.5 \\
31.0 \\
21.2 \\
15.0\end{array}$ & $\begin{array}{l}\mathbf{N} \\
\mathbf{N} \\
\mathbf{N} \\
\mathbf{N} \\
\mathbf{N} \\
\mathbf{N} \\
\mathrm{D} \\
\mathbf{N} \\
\mathbf{D} \\
\mathbf{D} \\
\mathbf{N} \\
\mathbf{N}\end{array}$ \\
\hline
\end{tabular}

TABLE IV-Mean ( $\pm S E)$ thyrotrophin $(T S H)$ concentrations in 11 patients before and after weight gain, and effect on $T S H$ increments $(\triangle T S H)$ during TSHreleasing hormone tests. Concentrations in $\mathrm{mU} / \mathrm{l}$. Basal values below $1 \mathrm{mU} / \mathrm{l}$ assumed to be $0.5 \mathrm{mU} / \mathrm{l}$

\begin{tabular}{|c|c|c|c|c|c|c|}
\hline & \multicolumn{6}{|c|}{ Time in minutes } \\
\hline & 0 & 20 & 60 & $\triangle 20$ & $\triangle 60$ & $\operatorname{Max} \triangle$ \\
\hline $\begin{array}{l}\text { Before } \\
\text { After }\end{array}$ & $\begin{array}{l}1.5 \pm 0.5 \\
2.4 \pm 0.7\end{array}$ & $\begin{array}{r}8 \cdot 3 \pm 1 \cdot 5 \\
16.8 \pm 3 \cdot 2\end{array}$ & $\begin{array}{r}8 \cdot 5 \pm 2 \cdot 0 \\
13 \cdot 8 \pm 3 \cdot 2 \\
\end{array}$ & $\begin{array}{r}6 \cdot 7 \pm 1 \cdot 2 \\
14 \cdot 4 \pm 2 \cdot 7\end{array}$ & $\begin{array}{r}6.9 \pm 1.5 \\
11.4 \pm 2.7\end{array}$ & $\begin{array}{r}7.9 \pm 1.5 \\
14.6 \pm 2.7\end{array}$ \\
\hline $\mathbf{P}$ & $>0.05$ & $<0.01$ & $<0.01$ & 0.016 & 0.035 & 0.012 \\
\hline
\end{tabular}

being found in nine cases; the other two patients had delayed responses.

\section{Discussion}

It is well established that T3 concentrations may be reduced in many severe and chronic non-thyroidal illnesses. ${ }^{9}$ Anorexia nervosa is no exception, and reduced T3 associated with an increased $\mathrm{T} 4 / \mathrm{T} 3$ ratio is well documented. ${ }^{610}$ When patients with anorexia are given a sub-replacement dose of oral T3 a greater reduction in their ankle reflex relaxation time than in normal controls has been observed, suggesting a tissue hormone deficiency. ${ }^{10}$ Circulating $\mathrm{T} 3$ is largely derived from peripheral deiodination of $\mathrm{T} 4$, but in systemic illness there may be preferential conversion of $\mathrm{T} 4$ to the inactive isomer $\mathrm{rT} 3 .^{11} \mathrm{We}$ found a raised rT3 concentration in some of our patients, which fell to within or below the normal range on refeeding. Such an increase in the metabolically inactive rT3 associated with reduced T3 may represent an adaptive process to limit catabolism and has also been described in protein-energy malnutrition $^{12}$ and in fasted obese subjects. ${ }^{13}$ In anorexia nervosa the $\mathrm{T} 3$ concentration increases on refeeding. ${ }^{10} \mathrm{We}$ found this increase to be linearly correlated with the percentage of ideal body weight, in agreement with Vigersky et al. ${ }^{14}$ Mean T4 concentrations, however, remained low throughout.

The lack of increase in basal TSH despite low T3 and T4 concentrations has been noted before ${ }^{914}$ and, if $\mathrm{rT} 3$ itself is assumed to play no part in the feedback inhibition of TSH release, must be due to an alteration in the "set-point" at which the pituitary thyrotroph cells are inhibited by thyroid hormones. This effect may be mediated via central dopaminergic pathways. Levodopa reduces TSH concentrations in hypothyroidism, ${ }^{15}$ and metoclopramide, a centrally acting dopamine receptor antagonist, increases $\mathrm{TSH}$ concentrations in normal ${ }^{16}$ and hypothyroid subjects, ${ }^{17}$ suggesting dopaminergic inhibitory control of TSH secretion. In our patients the pituitary TSH reserve was reduced at low body weight, which has also been shown for prolactin. ${ }^{18}$ This accords with the theory that there is excessive dopaminergic activity at central receptors in anorexia nervosa. ${ }^{19}$

It remains uncertain whether such an effect occurs mainly in the thyrotroph cells or is mediated indirectly via the hypo- thalamus. Evidence of hypothalamic dysfunction in anorexia nervosa, however, is found in the impaired diurnal variation of thyroidal iodide release, ${ }^{10}$ and in the delayed $\mathrm{TSH}$ response to $\mathrm{TRH}^{20}$ shown in some patients by ourselves and others. ${ }^{10}$

We conclude that changes in the hypothalamo-pituitarythyroid axis in anorexia nervosa are common and probably represent both peripheral and central adaptations to the altered nutritional state. Apart from the low mean T4 concentrations these changes are rapidly reversed on refeeding and weight gain

We thank Professor Barbara Clayton, Hospital for Sick Children, Great Ormond. Street, for providing antihuman TSH, and Dr Peter Dally for permission to study his patients.

Requests for reprints should be addressed to Sir Richard Bayliss.

\section{References}

${ }^{1}$ Gull, W W, Transactions of the Clinical Society of London, 1874, 7, 22.

${ }^{2}$ Mecklenburg, R S, et al, Medicine, 1974, 53, 147.

${ }^{3}$ Warren, M P, and Vande Wiele, R J, American fournal of Obstetrics and Gynecology, 1973, 117, 435.

4 Berkman, J N, American fournal of the Medical Sciences, 1930, 180, 411.

5 Fowler, P B S, Banim, S O, and Ikram, H, Lancet, 1972, 2, 307.

${ }^{6}$ Miyai, K, et al, fournal of Clinical Endocrinology and Metabolism, 1975, 40, 334 .

? Dally, P, Anorexia Nervosa. London, Heinemann, 1969.

${ }^{8}$ Ratcliffe, W A, Marshall, J, and Ratcliffe, J A, Clinical Endocrinology, $\mathrm{W}$ 1976, 5, 631 .

- Carter, J N, et al, Lancet, 1974, 2, 971.

10 Croxson, M S, and Ibbertson, H K, fournal of Clinical Endocrinology and Metabolism, 1977, 44, 167.

11 Chopra, I J, et al, fournal of Clinical Endocrinology and Metabolism, 1975, ?41, 1043.

12 Chopra, I J, and Smith, S R, Fournal of Clinical Endocrinology and Metabolism, 1975, 40, 221.

13 Vagenakis, A G, et al, fournal of Clinical Endocrinology and Metabolism, $1975,41,191$

14 Vigersky, R A, et al, Clinics in Endocrinology and Metabolism, 1976, 5, 517.

15 Rapaport, B, et al, fournal of Clinical Endocrinology and Metabolism, 1973, 36, 256 .

${ }^{16}$ Healey, D L, and Burger, H G, Clinical Endocrinology, 1977, 7, 195.

17 Scanlon, M F, et al, Lancet, 1977, 2, 421.

18 Isaacs, A J, et al, British Medical fournal, 1977, 2, 521.

19 Barry, V C, and Klawans, H L, fournal of Neural Transmission, 1976, $\stackrel{P}{\rightleftharpoons}$ 38, 107.

20 Hall, R, et al, Lancet, 1972, 1, 759.

(Accepted 23 Yune 1978) 